\title{
Podlesie, Site 6 - the First Obsidian Inventory of the Linear Pottery Culture Communities from the Polaniec Basin
}

\author{
Marcin Szeliga $^{a}$, Michał Przeździecki ${ }^{b}$ and Artur Grabarek ${ }^{c}$
}

\begin{abstract}
The article includes the presentation and preliminary characterisation of the obsidian inventory obtained during the five research seasons (2014-2018) at the site in Podlesie, Staszów district, Swiętokrzyskie voievodship. Currently, it is one of the largest collections of artefacts of this raw material related to the Linear Pottery culture (IO4 examples), and at the same time the first obtained from the Połaniec Basin mesoregion. In the light of the current state of research, it is also one of the few inventories of this culture (outside the Rzeszów settlement cluster), in which the share of obsidian exceeded $4 \%$. Its homogeneous nature and large size, as well as the obtained radiocarbon dates, to a very significant extent supplement the current knowledge about the initial phase of the Neolithic obsidian influx into the Upper Vistula basin area, at the end of the 6th millennium BC.
\end{abstract}

KEY-WORDS: Linear Pottery Culture, music-note and Želiezovce phases, radiocarbon data, obsidian, processing, Upper Vistula basin.

\section{INTRODUCTION}

The inflow of obsidian into the areas on the northern side of the Carpathians and Sudetes is documented for the Older and Middle Stone Age (e.g. Kostrzewski 1930: 95-96; Biró 1985: Fig. I; Ginter 1986; Szeliga 2002; Hughes et al. 2018). The greatest intensity of this phenomenon, however, took place in the Neolithic period, closely tied with the Danubian cultural groups, which maintained intensive contacts with the Transcarpathian zone throughout the whole period of its development. In the light of the current state of knowledge, the Neolithic import of obsidian into the Vistula and

a Institute of Archaeology, Maria Curie-Skłodowska University in Lublin, 4. M. C.-Skłodowska sq, 20-03I Lublin, Poland, e-mail: marcin.szeliga@poczta.umcs.lublin.pl ORCID: 0000-0002-5I85-073X

${ }^{b}$ Institute of Archaeology, University of Warsaw, 26/28 Krakowskie Przedmieście st., 00-927 Warsaw, Poland, e-mail: przezdziecki@uw.edu.pl ORCID: 00oo-0002-8605-394I

c Institute of Archaeology, University of Warsaw, 26/28 Krakowskie Przedmieście st., 00-927 Warsaw, Poland, e-mail: a.grabarek@uw.edu.pl ORCID: 0000-0003-2670-4519 
I98 $\mid$ Marcin Szeliga, Michat Przeździecki, Artur Grabarek

Oder river basins lasted almost continuously from the end of the 6th to about the middle of the $4^{\text {th }}$ millennia $\mathrm{BC}$, with a varying degree of intensity and involving a various forms of inflow (e.g. Kozłowski 1970: 89; Kaczanowska 1980; 1985: 65; Szeliga 2007; 2009; Wilczyński 2010). Particularly interesting is the initial phase of this phenomenon, taking place during the development of the Linear Pottery culture (hereinafter LBK) and by far represented by the largest number of inventories, which also represent the most extensive range of territorial spread (Szeliga 2009: Fig. I; tab. I). This article, including the presentation and preliminary characterisation of the first so-dated obsidian inventory from the Połaniec Basin, is a small but quite significant contribution to the study of the whole phenomenon of the inflow of this exotic material and its processing by the early agricultural communities settled in the Upper Vistula basin at the end of the 6th millennium BC.

\section{THE INFLOW OF OBSIDIAN DURING THE LBK DEVELOPMENT}

The Neolithic inflow of obsidian into the areas located to the north of the Carpathians was initiated in the classical (music-note) phase of the LBK, and intensified in the late - Želiezovce stage of its stylistic development (e.g. Kaczanowska I971: I2-I3; 1976: 38; Godłowska 1976: 91-92; Kulczycka-Leciejewiczowa 1979: 85; Kadrow 1990a: ryc. 24: a-i; 26: c; Szeliga 2007: Abb. I; 2009: 298-304). Currently several dozen sites dated to this period are known in those areas, where the products made of this raw material have been found. The vast majority of them create a several distinct clusters in the upland loess zone of southern and south-eastern Poland (Przemyśl, Rzeszów, Targowisko and Brzezie, Cracow-Nowa Huta and Sandomierz regions). Less numerous are sites located outside this area, sometimes at a very large distance from it (Szeliga 2009: Fig. I).

Despite the large number of inventories (territorially scattered), the amount of obsidian products is generally small, ranging from a single specimens to several dozen examples (Szeliga 2009: tab. I). Only few sites from the Upper Vistula basin have provided assemblages containing over a dozen pieces (e.g. Rzeszów, site I6, Brzezie, site I7; see Kadrow I990a: 33; Wilczyński 20I4: 500), and even over 200 artefacts (e.g. Cracow-Olszanica, site 4; see Milisauskas I983: tab. 4). Regardless of the size of particular inventories, the percentage of obsidian in the structure of their raw material is usually very low and does not exceed $2-3 \%$, and only sporadically reaches higher values (e.g. Kozłowski 1970: tab. I; Godłowska 1982: I53; Milisauskas 1986: I45; Kaczanowska et al. 1987: 94; Michalak-Ścibior and Taras 1995: tab. V; Wilczyński 20I4: tab. 2). This points to the minimal, practically irrelevant importance of this material for production, and thus - to its inflow into particular settlements without economical justification. Only some of the inventories of the material from the Rzeszów settlement cluster 

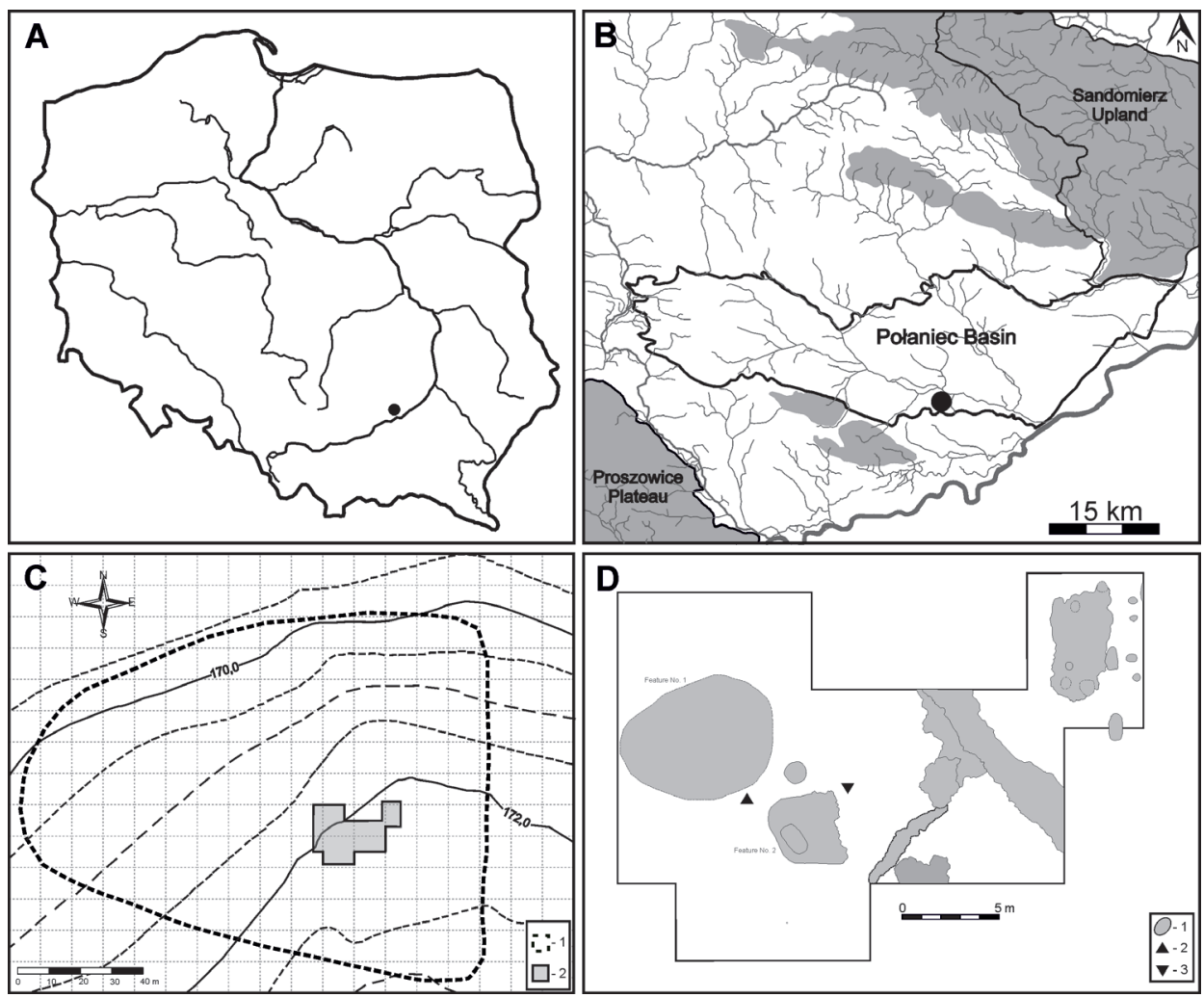

Fig. I. Podlesie, site 6. Analysed area: A - general location of the site; B - location of site within the Połaniec Basin (by Kondracki 2002); C - the extent of the site in the context of the site grid (I) with area excavated in 20I4-20I8 (2); D - location of LBK features (I) and dated ceramic samples (2 - sample PDL6_A; 3 - sample PDL6_B); features No. I and 2 - features with obsidian artefacts.

Prepared by A. Grabarek and M. Szeliga.

deviate from this situation. In these, the percentage of obsidian exceeds many times the values known from other areas and keeps a high frequency throughout the entire LBK development period (e.g. Kraczkowa, site I, Rzeszów, sites I6 and 34, Zwięczyca, site 3; see Kulczycka-Leciejewiczowa 1979: tab. 5, ryc. 26; Kaczanowska 1985: Abb. 22; Kadrow 1990a: Fig. 24a-e; 26c; 1990b: Fig. I4a-c; Pelisiak 20I4: tab. I4). These data indicate a completely different significance of the obsidian in local processing, justifying the perception of local LBK communities as one of its most important recipients and users, most likely mediating and controlling its redistribution to more remote settlement centres (Szeliga 2009: 298-299). 

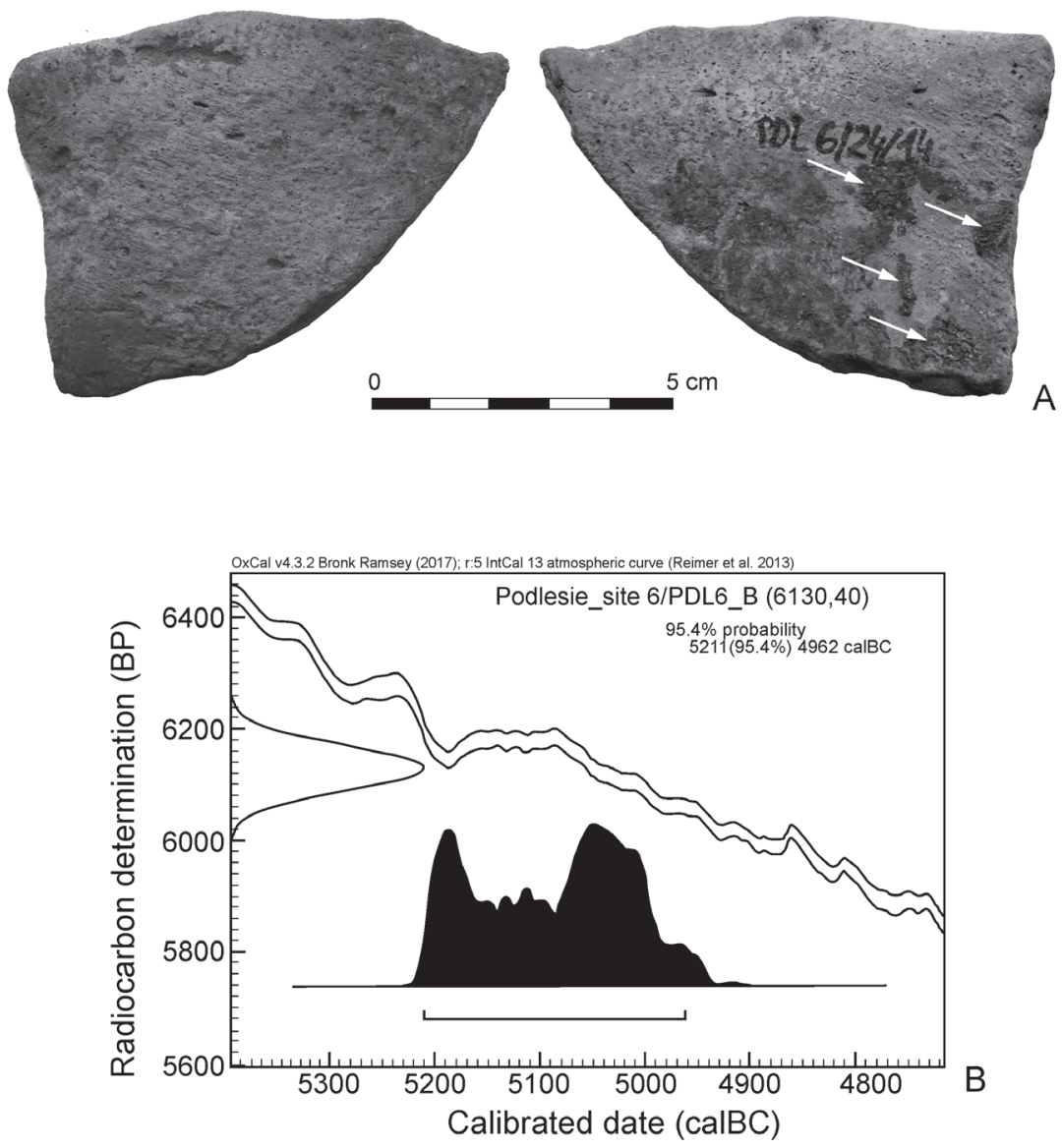

Fig. 2. Podlesie, site 6. Fragment of a LBK vessel with preserved organic substance - sample PDL_B (A) and the calibration curve of I4C date obtained on its basis (B).

Prepared by M. Szeliga.

The current analysis of the findings indicates that obsidian was flowing into the southern Poland LBK settlement centres in the form of natural concretions (e.g. Kozłowski 1970: 89; Godłowska 1982: 92; Kaczanowska 1985: 65; Szeliga 2009: 303). Although the results of previous chemical analyses confirm the presence of products made of both Slovak (Carpathian I) and Hungarian (Carpathian 2) varieties of this raw material in such dated inventories (Milisauskas 1983: 172; 1986: tab. 92), it seems that the obsidian from the Slovak outcrops was the most important. This is indicated by the recent results of the Prompt Gamma Activation Analysis, carried out for a series of products 
from Kuyavia and Podkarpacie, allowing identification of the origin of the raw material with the areas near Cejkov and Kašov in south-eastern Slovakia (Kabaciński et al. 2015: IO-I2). They correspond to the results of geochemical analyses of obsidian artefacts originating from Czech inventories (Burgert et al. 2016: Obr. 4-5), as well as the findings of A. Přichystal and P. Škrdla (20I4: 224), justifying the location of the most important obsidian outcrops exploited in prehistory in a small area between Brehov, Cejkov and Zemplín.

In the context of the presented data, the collection obtained in recent years on the site 6 in Podlesie, Staszów district, Świętokrzyskie voievodeship clearly stands out. It is currently one of the largest LBK obsidian inventories (IO4 artefacts), and the first one obtained by excavation in the Połaniec Basin. The large number of items and presumably homogeneous nature, as well as the possibility of precise dating of this collection make this assemblage quite unique in the context of other LBK findings and inventories known from the Upper Vistula Basin.

\section{THE LBK SETTLEMENT IN PODLESIE}

Site No. 6 in Podlesie is located in the central part of the Połaniec Basin, a part of the Małopolska Upland (Kondracki 2002: 269-270). It occupies a fragment of the southern, gentle slope and the edge of the Wschodnia river valley (Fig. IA-C). It is based on Pleistocene clays from the Sanian and Odranian glaciations and diluvial sediments covering the Miocene Cracow loams. The current soil cover is formed by lessive soils. Based on the results of surface and geophysical surveys, as well as drilling, the size of the site is estimated at about 2 ha (Fig. IC).

The site was accidentally discovered in 2009 by one of the villagers. Since 20I4, it has been the subject of systematic excavations under the direction of Artur Grabarek from the Institute of Archaeology at the University of Warsaw. So far, a total area of 3.8 ares has been examined, where Io immobile features were discovered and explored. The research was carried out manually, with the use of hoes, and the feature fills were partially floatated or screened. The research methodology applied allowed a very large collection of artefacts to be obtained. These finds consist of a total number of approximately 14.500 products of various categories, mainly ceramics, and to a lesser extent flint artefacts (Przeździecki et al., in print). All features and all artefacts are related to the LBK. The analysis of technological features and stylistics of the ceramic's ornamentation allows for the chronological location of the whole collection at least between the classical section of the music-note phase and the early stage of the Želiezovce phase (i.e. NII - ŽI; see Pavúk 1969: 275-277; Kadrow I990a: 62), with a clear quantitative dominance of materials decorated in classical and late music-note style. This classification corresponds very well with the occurrence of single fragments of vessels deco- 
rated in the manner typical for the Eastern-Linear groups, mainly for the KapušanyTiszadob group and the Bükk culture (Przeździecki et al., in print).

\section{CHRONOLOGICAL DATA}

The site's absolute chronology was determined on the basis of two organic samples, macroscopically similar to birch tar (Fig. 2A), obtained from two diagnostic fragments of thin-walled LBK vessels, originating from the cultural layer in different parts of the excavation trench from a depth of about $80 \mathrm{~cm}$, in the vicinity of feature No. 2 (Fig. ID). Both samples were dated using the AMS technique at the Poznań Radiocarbon Laboratory. The following dates were obtained: a/ 4710 \pm 50 BP; b/ 6130 $\pm 40 \mathrm{BP}$ (Tab. I, Fig. 2B). The first of these dates should be rejected as definitely too late for LBK, presumably because of the organic matter contamination or from the small content of carbon (Tab. I). The second date would fall in the chronological frames defined for the LBK music-note phase in south-eastern Poland (Czekaj-Zastawny 2008: II6). This date therefore documents the settlement of the site by communities of this culture, as well as the inflow and use of obsidian resources at least at the end of 6th millennium BC (Fig. 2B). It also corresponds with radiocarbon dates of obsidian inventories originating from various settlement centres of this culture, in the Rzeszów area (Zwięczyca, site 3, feature No. 36; see Dębiec 20I4: IO7-IO8; Pelisiak 20I4: tab. 2I), as well as in the Cracow region (Brzezie, site 17, features No. 238 and 377; see CzekajZastawny 2008: tab. I; Wilczyński 20I4: tab. 3) and Sandomierz region (Tominy, site 6, feature No. I08; see Szeliga 20I7: tab. I, Fig. 6: 3).

\section{OBSIDIAN INVENTORY}

The assemblage presented here of obsidian products contained a total number of IO4 artefacts, constituting about $4.79 \%$ of the whole raw material structure of the lithic inventory (Fig. 3A). The vast majority of them were discovered within non-feature cultural layers, and 3I specimens during the exploration of the features No. I (I7 pieces) and No. 2 (I4 pieces). In spite of the context of most of the finds, their relation to the LBK is not in doubt, due to the homogeneous nature of all historical materials (including ceramics) obtained from the site during the previous research.

The analysed products reveal a considerable degree of differentiation of their macroscopic properties, above all the colour and transparency. By far, the most numerous group are artefacts made of black material, often in material with a streaked internal structure, translucent only in the thinnest, edge parts. They are complemented by much less numerous specimens made of a transparent material of grey or grey-black 
$\mathrm{N}=\mathbf{2 1 7 2}$

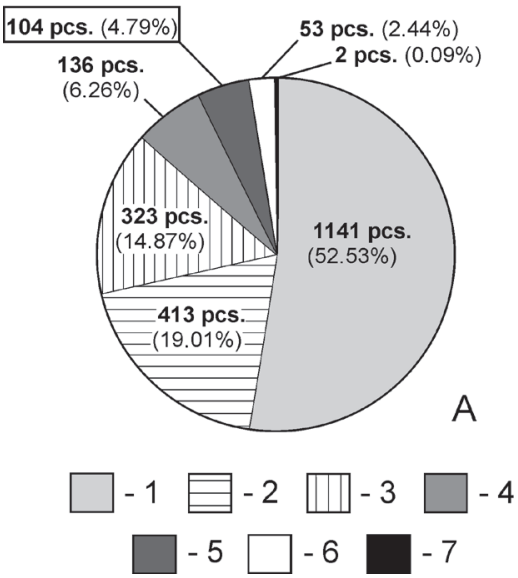

$\mathrm{N}=\mathbf{2 1 7 2}$

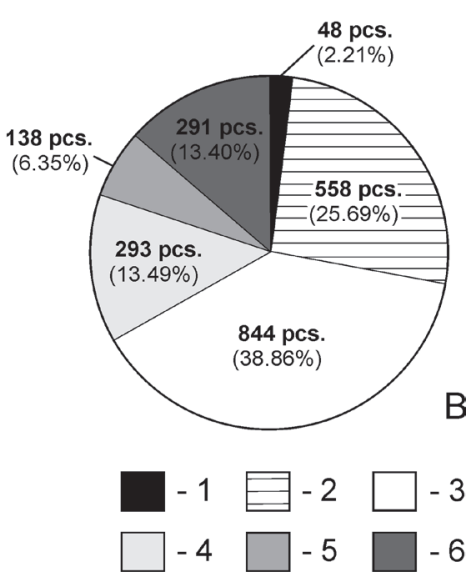

Fig. 3. Podlesie, site 6. Cumulative structure of flint and obsidian artefacts obtained in 20I4-20I8

(after Przeździecki et al., in print): A - raw material structure ( - Jurassic-Cracow flint;

2 - Świeciechów flint; 3 - Chocolate flint; 4 - Undefined (burned) flint; 5 - Obsidian; 6 - Erratic flint; 7 - Banded flint); B -morphological structure ( $\mathrm{I}$ - cores; 2 - blades and their fragments; 3 - flakes; 4 - chips; 5 - sherds; 6 - retouched tools).

\section{$\mathrm{N}=104$}
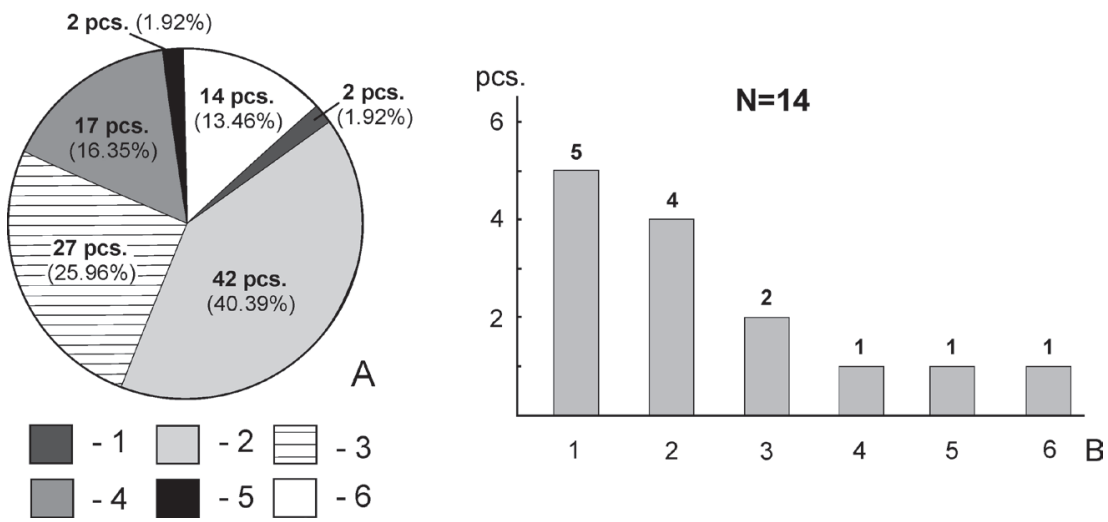

Fig. 4. Podlesie, site 6: obsidian inventory structure $A$ - morphological differentiation of the collection ( $\mathrm{I}$ - cores; 2 - blades and their fragments; 3 - flakes; 4-chips; 5 -sherds; 6 - retouched tools); B - typological differentiation of the tools ( 1 - retouched blades; 2 - endscrapers; 3 - blades with lateral retouch; 4 - truncated blade; 5 - scraper; 6 - perforator). Prepared by M. Przeździecki. 
204 Marcin Szeliga, Michat Przeździecki, Artur Grabarek

Table I. Podlesie, site 6. Juxtaposition and calibration of obtained ${ }_{4} 4 \mathrm{C}$ dates. Prepared by M. Szeliga.

\begin{tabular}{|c|c|c|c|c|c|c|}
\hline \multirow[b]{2}{*}{$\begin{array}{l}\text { Symbol of } \\
\text { sample }\end{array}$} & \multirow{2}{*}{$\begin{array}{l}\text { Laboratory, } \\
\text { number of } \\
\text { sample }\end{array}$} & \multirow[b]{2}{*}{$\begin{array}{l}\text { I4C data } \\
\text { [BP] }\end{array}$} & \multirow[b]{2}{*}{$\begin{array}{l}\text { Kind of } \\
\text { sample }\end{array}$} & \multicolumn{2}{|c|}{ Calibration - after Ramsey 2013} & \multirow[b]{2}{*}{ Comments } \\
\hline & & & & $\begin{array}{l}68.2 \% \\
\text { probability }\end{array}$ & $\begin{array}{l}95.4 \% \\
\text { probability }\end{array}$ & \\
\hline PDL6_A & Poz-102101 & $4710 \pm 50$ & $\begin{array}{l}\text { Wood } \\
\text { tar }\end{array}$ & $\begin{array}{l}3627-3589 \text { BC } \\
(17.1 \%) \\
3528-3498 \text { BC } \\
(14.7 \%) \\
3454-3377 \text { BC } \\
(36.4 \%)\end{array}$ & $\begin{array}{l}3634-3552 \mathrm{BC} \\
(29.3 \%) \\
3541-3484 \mathrm{BC} \\
(21.7 \%) \\
3475-3370 \mathrm{BC} \\
(44.4 \%)\end{array}$ & $\begin{array}{l}{ }^{*} \text { small, } 0.12 \\
\text { mg C }\end{array}$ \\
\hline PDL6_B & Poz-101824 & $6130 \pm 40$ & $\begin{array}{l}\text { Wood } \\
\text { tar }\end{array}$ & $\begin{array}{l}5206-5162 \text { BC } \\
(20.6 \%) \\
5136-5130 \mathrm{BC} \\
(2.1 \%) \\
5120-5107 \mathrm{BC} \\
(4.3 \%) \\
5080-4997 \mathrm{BC} \\
(41.3 \%)\end{array}$ & $\begin{array}{l}5211-4962 \mathrm{BC} \\
(95.4 \%)\end{array}$ & \\
\hline
\end{tabular}

colour. This differentiation may indicate the origin of the raw material from various Slovak-Hungarian outcrops (Williams-Thorpe et al. 1984: I83).

In terms of techno-typology, three basic categories of products can be singled out in the presented inventory, containing:

a/ debitage products, including cores, blades, flakes and chips (88 specimens in total $-84.62 \%)$,

b/ debitage modification products, represented by retouched tools (I4 examples I3.46\%; see: Fig. $4 \mathrm{~A}$ ),

c/ unspecified destructed sherds, including two (I.92\%) non-characteristic, polyhedral fragments with a difficult to determine technological origin.

Within the first of the distinguished categories, cores are represented only by two small and heavily exploited artefacts: a flat bipolar splintered piece with cortical background (dimensions: 23 [height] x I4 [width] x 6 [thickness] mm; Fig. 5: 2) and a slightly larger (3I x $23 \times 25 \mathrm{~mm}$ ), regular single-platform blade core (Fig. 5: I). Its flaking surface (located on the wider side of the concretion) is characterized by a small horizontal convexity and a clear incline at the base. The well-planned layout, 
morphological coherence and above all - the lack of hinge points and blades tendency to incurve in distal part (so-called overshot forms), indicate a high level of the knapper's skills (no errors, control of the knapped blanks parameters). The platform preparation method has a characteristic division into a passive and active zone (see Wąs 2005: I3I, fig. 56). The first of them is formed by large, but gently wedged scars with a concentric arrangement, resulting from several percussions from the left side of the core. In turn, the range of the active platform zone is determined by short and very fine scars with hinged ends, overlapping in a small area within the edge part of the platform (Fig. 4: I). Probably the unfavourable angular relations between the flaking surface and the platform were the main reason for refraining from further blank exploitation, and consequently abandoning the core. The attempt to correct the core angle, although technically possible, was probably unprofitable, entailing a radical shortening of an already very small core.

The largest group are blades and their fragments ( 42 artefacts $-40.38 \%$, see: Fig. $4 \mathrm{~A}$ ). They are represented only by medio-lithic or sub-microlithic examples, usually without cortex, with uni-directional dorsal pattern (Fig. 5: 6-I6). Whole blades and proximal fragments have multi-scar butts, prepared by means of several precise percussions on the flaking surface, while the values of the core angle oscillate around $90^{\circ}-95^{\circ}$. Attention is also drawn to the relatively large (laterally spread), though slightly arched bulbs, often co-occurring with a characteristic flaw in the form of a small scar (Fig. 5: 7-8, I2). These features are closely related both to the method of exploitation (i.e. the implementation of the serial debitage concept), as well as the technique of applying the impact force, most likely by indirect percussion using a soft punch (e.g. Iznian et al. I999: 32). Particular attention is paid to a set of I4 fragments of regular, most probably intentionally broken, blades. They are characterized by the presence of more or less visible areas of damage of the edges, sometimes accompanied by single, very fine scars, usually occurring flatly on one of the edge surfaces (Fig. 5: 6, 9-10, I2-I3). The nature, degree of intensity and repeatability of recorded macro-traces suggest their utilitarian genesis, justifying their interpretation as functional tools, probably used for activities of a similar nature. Planned micro-wear analyses probably will enable the verification of this hypothesis.

A slightly less numerous group are flakes (27 artefacts) and chips (I7 specimens), comprising a total of $42.31 \%$ of the analysed collection (Fig. $4 \mathrm{~A}$ ). They are mostly of non-characteristic form, revealing a high degree of morphological and metric variations. The vast majority of them are pieces completely devoid of the cortex surfaces or with small areas of cortex on the upper surface. This group includes both the products of blade or flake core preparation (Fig. 5:3), as well as their repairs during the exploitation of the blanks, related in particular to the core's angle correction (Fig. 5:4) and the remains of unsuccessful blade knapping (Fig. 5: 5). 

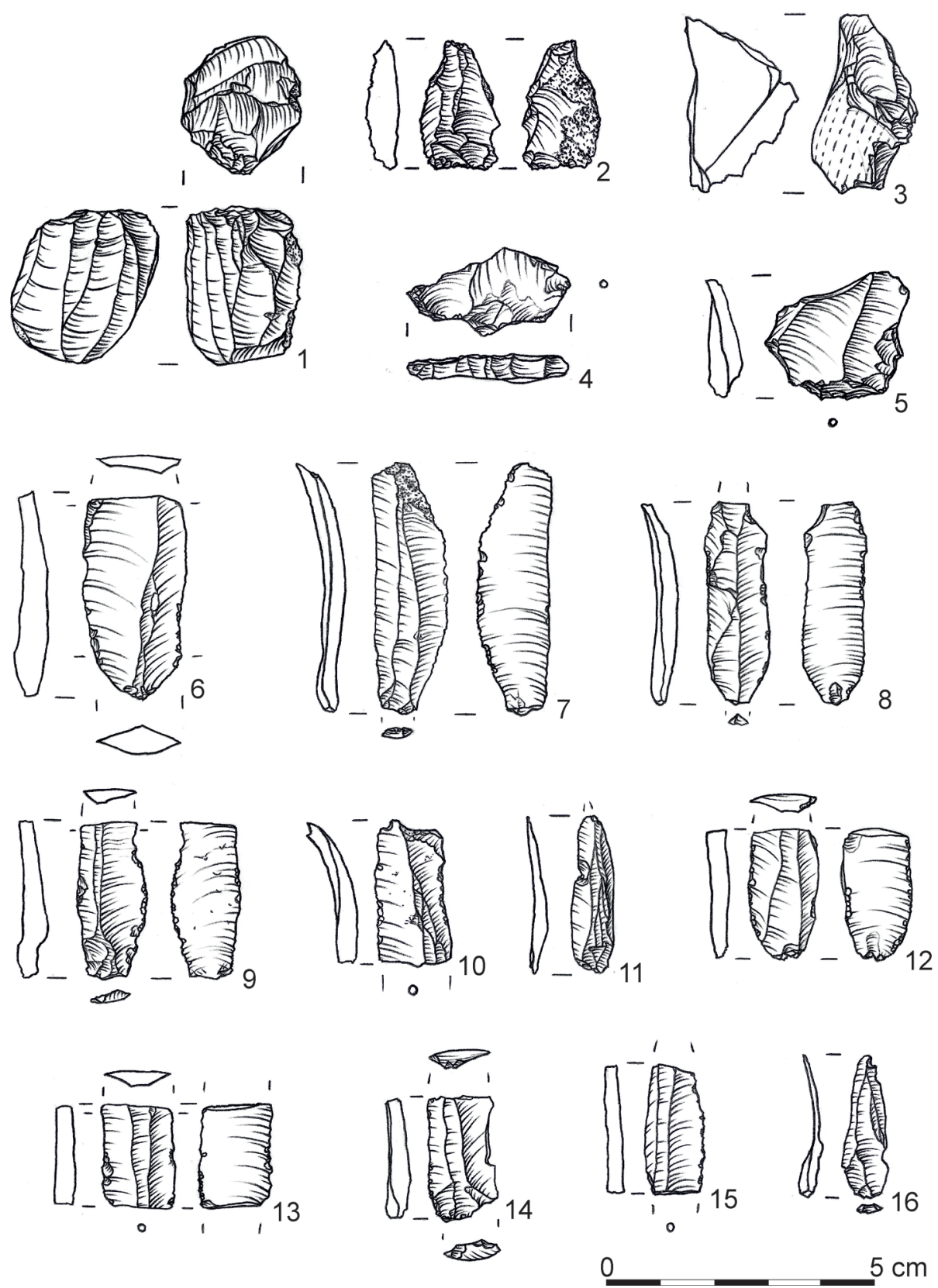

Fig. 5. Podlesie, site 6: selection of the obsidian finds obtained from non-feature layers $(\mathrm{I}-3,5,7-8$, IO-I2, I5-I6), feature No. 2/2OI4 (4, 6, 9) and feature No. I/2OI4 (I3-I4): I- blade core; 2-bipolar splintered piece; 3-5- flakes; 6-16 - blades. Drawing by A. Pałasz. 
\begin{tabular}{l|l} 
Podlesie, Site 6 - the First Obsidian Inventory of the Linear Pottery Culture ... & 207
\end{tabular}
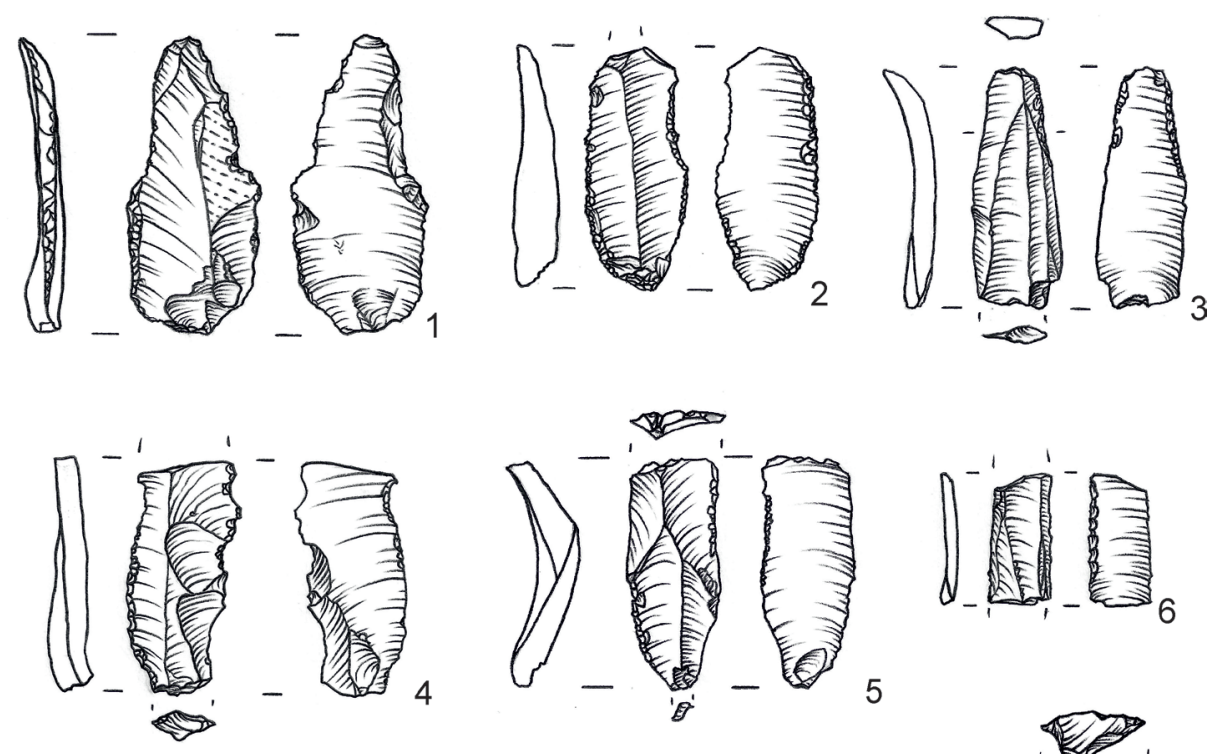

5
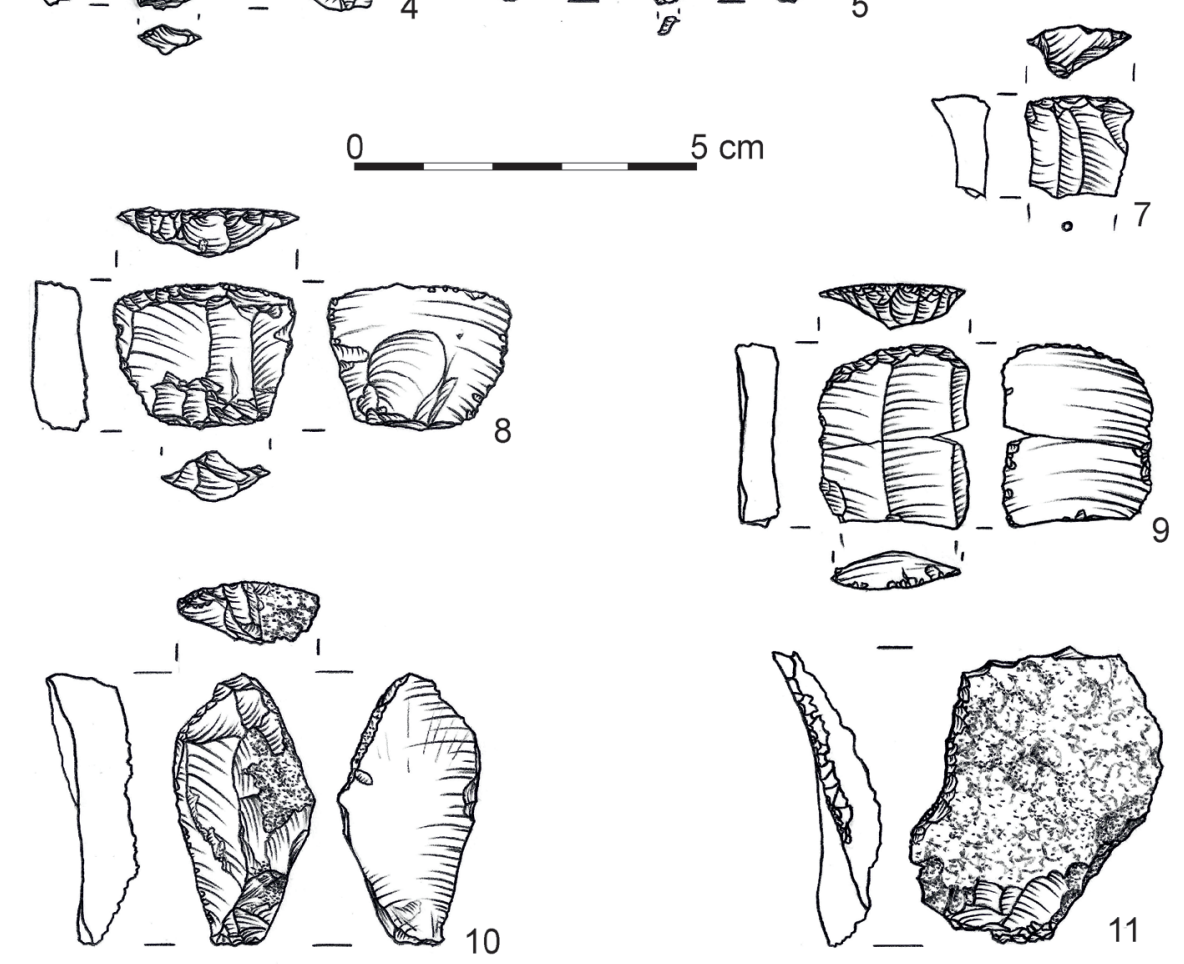

$5 \mathrm{~cm}$

Fig. 6. Podlesie, site 6: selection of the obsidian finds obtained from non-feature layers (I, 3-4, 6-9, II), feature No. 2/20I4 (2, IO) and feature No. I/20I4 (5): I - perforator; 2-4, 6-retouched blades; 5 - truncated blade; 7-IO - endscrapers; II - scraper. Drawing by A. Pałasz. 
208 Marcin Szeliga, Michat Przeździecki, Artur Grabarek

Debitage modification products are represented by I4 morphological tools, representing about $13.46 \%$ of all obsidian finds (Fig. $4 \mathrm{~A}$ ). This collection, despite its small size, is characterized by a fairly large degree of typological diversity. The most numerous group are retouched blades ( 7 examples, Fig. 4B) made of blanks from the advanced phase of the exploitation of single platform cores, most often from non-cortical specimens (Fig. 6: 2-4). They do not reveal any regularity in the distribution, course or formation manner of the particular edges, including pieces with straight or convex edges, retouched on various section lengths (Fig. 6: 3-4, 6), as well as examples with various notches (Fig. 6: 2). A smaller group are endscrapers (4 artefacts, Fig. 4B), made on two regular scar blades (Figures 6: 7, 9), on a massive, partially cortical crested blade (Fig. 6: Io) and on a flake (Fig. 6: 8), originating from the blade-core flaking debitage surface reduction (resulting from unsuccessful blade percussion of the striking platform side, the so-called IIIBI flake, see: B. Balcer 1975: 82). The other retouched tools are represented by single specimens: a regular truncated blade (Fig. 6: 5), a scraper on a massive, cortical flake (Fig. 6: II) and a perforator with hardly formed point (Fig. 6: I).

\section{CONCLUSIONS}

The results of the conducted analyses indicate the homogeneous nature of the obsidian collection from Podlesie, in terms of stylistics, technology and typology, at the same time revealing very important convergences with the flint material produced by the site (Przeździecki et al., in print). That justifies the interpretation of the entire inventory as chronologically and culturally homogeneous in relation to the LBK settlement of the site at the end of the 6 th millennium BC. The obtained results correspond also with the results of other analyses of obsidian inventories from the area of the Upper Vistula basin. Clear convergences are readable both in the general structures of inventories, as well as the frequency of particular categories of products, in each case including the dominance of debitage and generally very low or even minimal content of cores (Milisauskas 1983: tab. I; Kaczanowska 1985: Abb. 23-24; Pelisiak 20I4: tab. I4). On the other hand, a differentiating feature is the proportion of retouched tools in the analysed collection (I4 specimens $-13.46 \%$, see: Fig. 3A-B), comparable only with a very few other inventories, i. a. Cracow-Olszanica (Milisauskas 1986: tab. 93-94). The occurrence of this category of products at LBK sites is usually limited to a maximum of several artefacts (e.g. Kadrow I990a: fig. 26: a; Pelisiak 20I4: tab. I4-I5; Wilczyński 20I4: 500).

Similarities to other LBK obsidian inventories are also seen at the level of the general scope of this raw material processing and basic production trends, and to a lesser extent also the forms of its inflow. The low percentage of cortical pieces in the analysed collection suggests that obsidian reached the inhabitants of the Podlesie settlement in the form of prepared blade cores that were subjected to a complex processing on the 
spot, oriented to the production of regular, though small, blanks. An analogous range of production activity is visible in the case of all the most-important inventories known from southern and south-eastern Poland (Szeliga 2009: 302-305). Possible differences can only be related to the form of obsidian inflow into local settlements, documented - in the case of the Cracow and Rzeszów clusters - in the form of natural concretions. It seems that these differences do not have any significant economic importance. In addition, the lack of nodules of this raw material in the Podlesie site may result only from the present small degree of its examination.

In the view of low degree of exploration of the Podlesie settlement, a fortiori the high percentage of obsidian should be emphasized, reaching the value of $4.79 \%$ (Fig. 3A). Although this proportion reflects its marginal economic significance in the local processing and tool production, it significantly exceeds the obsidian percentage in almost all LBK inventories known from the areas between the Sandomierz Upland, Proszowice Plateau and Miechów Upland (e.g. Godłowska 1976: 9I-92; Kulczycka-Leciejewiczowa 1979: Fig. 26; Kaczanowska 1985: Abb. 22; Michalak-Ścibior and Taras 1995: tab. V; Szeliga 2008: Fig. I2). Currently, the only known inventory of higher obsidian percentage in the collective raw material structure originates from site No. $4 \mathrm{I}$ in Cracow-Nowa Huta-Krzesławice (about I0.7\%), but it is entirely related to the younger, Želiezovce phase of this culture development (Godłowska 1982: 153). Therefore, the presented collection from Podlesie is the second LBK inventory (connected probably mainly with the music-note phase of its development), located outside the Rzeszów settlement cluster, in which the percentage of the obsidian exceeded the level of 4\% (Szeliga 2009: Fig. 3). The discussed site is also the only excavated LBK settlement within the Połaniec Basin, and the acquired material culture assemblage is the only evidence confirming the influx of obsidian at the end of the 6th millennium BC. Whether the percentage of obsidian in Podlesie reflects the actual scale of its import and high economic importance for the local LBK communities, or is "only" the effect of applying high methodological standards during fieldwork, is currently an open question, which undoubtedly requires verification in the course of further research. Irrespective of this, the acquisition of the first and also so numerous obsidian inventory from the Połaniec Basin, along with the radiocarbon dates referring to this material, significantly supplements the current knowledge of the initial phase of obsidian inflow into the Upper Vistula basin in the Neolithic, dated at least at the end of the 6th millennium BC.

\section{ACKNOWLEDGEMENTS}

The radiocarbon analyses were financed by the National Science Centre in Poland (OPUS Iо; DEC-2015/19/B/HS3/or720). 
210 Marcin Szeliga, Michat Przeździecki, Artur Grabarek

\section{REFERENCES}

Balcer, B. 1975. Krzemień świeciechowski w kulturze pucharów lejkowatych. Eksploatacja, obróbka i rozprzestrzenienie. Wrocław-Warszawa-Kraków-Gdańsk.

Biró, K.T. 1985. Distribution of Obsidian from the Carpathian Sources on Central European Paleolithic and Mesolithic Sites. Acta Archaeologica Carpathica 23: 5-42.

Burgert, P., Přichystal, A., Prokeš, L., Petřík, J. and Hušková, S. 20I6. Původ obsidiánové suroviny vpravěku Čech. Archeologické rozhledy 68: 224-234.

Czekaj-Zastawny, A. 2008. Osadnictwo spoteczności kultury ceramiki wstęgowej rytej w dorzeczu górnej Wisty. Kraków.

Dębiec, M. 20I4. Zwięczyca 3. Eine bandkeramische Siedlung am Wistok. Rzeszów.

Ginter, B. 1986. Obsidianimporte im Spätpaläolithikum und Mesolithikum in Südpolen. In B. Chropovský (ed.), Urzeitliche und Frühistorische Besiedlung der Ostslowakei in Bezug zu den Nachbargebieten, 7I-76. Nitra.

Godłowska, M. 1976. Próba rekonstrukcji rozwoju osadnictwa neolitycznego w rejonie Nowej Huty. Materiaty Archeologiczne Nowej Huty 5: 7-180.

Godłowska, M. 1982. Nowohucki zespół osadniczy na tle wpływów południowych we wczesnym i środkowym neolicie Małopolski. Wiadomości Archeologiczne 47: 143-160.

Hughes, R.E., Werra, D. H. and Sulgostowska, Z. 20I8. On the sources and uses of obsidian during the Paleolithic and Mesolithic in Poland. Quaternary International 468: 84-IOO.

Iznian, M-L., Reduron-Ballinger, M., Roche, H. and Tixier J. 1999. Technology and terminology of Knapped Stone. Nanterre. Préhistoire de la pierre taillée 5.

Kabaciński, J., Sobkowiak-Tabaka, I., Kasztovszky, Zs., Pietrzak, S., Langer, J. J., Biró, K. T. and Maróti, B. 20I5. Transcarpathian influences in the Early Neolithic of Poland. A case study of Kowalewko and Rudna Wielka sites. Acta Archaeologica Carpathica 50: 5-32.

Kaczanowska, M. I97I. Krzemienne materiały kultur neolitycznych pochodzenia południowego z terenu Nowej Huty. In J.K. Kozłowski (ed.), Z badań nad krzemieniarstwem neolitycznym i neolitycznym, IO-24. Kraków.

Kaczanowska, M. 1976. Uwagi o kontaktach między terenami Małopolski i Słowacji w neolicie i eneolicie w świetle importów surowców kamiennych. Materiaty Archeologiczne 16: 37-4I.

Kaczanowska, M. 1980. Uwagi o surowcach, technice i typologii przemysłu krzemiennego kultury bodrogkereszturskiej i grupy Lažňany. Acta Archaeologica Carpathica 20: 19-56.

Kaczanowska, M. 1985. Rohstoffe, Technik und Typologie der Neolithischen Feuersteinindustrien im Nordteil des Flussgebietes der Mitteldonau. Warszawa.

Kaczanowska, M., Kozłowski, J. K. and Zakościelna, A. 1987. Chipped Stone Industries of the Linear Band Pottery Culture Settlements in the Nowa Huta Region. Przeglad Archeologiczny 34: 93-I32.

Kadrow, S. I990a. Osada neolityczna na stan. nr I6 w Rzeszowie na Osiedlu Piastów. Sprawozdania Archeologiczne 4I: 9-76.

Kadrow, S. 1990b. The Rzeszów Settlement Microregion in Neolithic. Acta Archaeologica Carpathica 29: 33-70.

Kondracki, J. 2002. Geografia regionalna Polski. Warszawa.

Kostrzewski, J. 1930. Obsidian Implements found in Poland. Man. A Monthly Record of Anthropological Science 30: 95-98.

Kozłowski, J. K. I970. Z badań nad wytwórczością krzemieniarską w kulturze ceramiki wstęgowej rytej. In J. K. Kozłowski (ed.), Z badań nad kulturą ceramiki wstęgowej rytej, 73-94. Kraków. 
Kulczycka-Leciejewiczowa, A. 1979. Pierwsze społeczeństwa rolnicze na ziemiach polskich. Kultury kręgu naddunajskiego. In W. Hensel and T. Wiślański (eds), Neolit, 19-165. Wrocław-WarszawaKraków-Gdańsk. Prahistoria ziem polskich, t. II.

Michalak-Ścibior, J. and Taras, H. 1995. Wczesnoneolityczna osada w Sandomierzu-Krukowie, stan. 20. Sprawozdania Archeologiczne 47: 69-134.

Milisauskas, S. 1983. Bandkeramische Obsidianartefakte aus Olszanica. Archäologisches Korrespondentzblatt I3: I7I-I75.

Milisauskas, S. 1986. Early Neolithic Settlement and Society at Olszanica. Ann Arbor. Memoirs of the Museum of Anthropology. University of Michigan 19.

Pavúk, J. I969. Chronologie der Želiezovce-Gruppe. Slovenská Archeológia I7(2): 269-367.

Pelisiak, A. 20I4. Steinfunde. In M. Dębiec, Zwięczyca 3. Eine bandkeramische Siedlung am Wistok, IIO-I35. Rzeszów.

Przeździecki, M., Szubski M. and Grabarek, A. In print. Między wschodem a zachodem. Inwentarz krzemienny z osady ludności kultury ceramiki wstęgowej rytej na stanowisku Podlesie 6, woj. świętokrzyskie. In Krzemień jurajski w pradziejach. Studia nad gospodarką surowcami krzemiennymi w pradziejach 9.

Přichystal, A. and Škrdla, P. 20I4. Kde ležel hlavní zdroj obsidiánu v pravěku střední Evropy? Slovenská Archeológia 62(2): 215-226.

Ramsey, B. 2017. OxCal v4.3.2. Internet Program.

Szeliga, M. 2002. Stan badań nad napływem obsydianu na ziemie polskie w starszej i środkowej epoce kamienia (na tle znalezisk środkowoeuropejskich). In J. Gancarski (ed.), Starsza i środkowa epoka kamienia w Karpatach polskich, 339-357. Krosno.

Szeliga, M. 2007. Der Zufluss und die Bedeutung des Karpatenobsidians in der Rohstoffwirtschaft der Postlinearen Donaugemeinschaften auf den polnischen Gebieten. In J. K. Kozłowski and P. Raczky (eds), The Lengyel, Polgár and related cultures in the Middle/Late Neolithic in Central Europe, 295-307. Kraków.

Szeliga, M. 2008. Kontynuacja badań wykopaliskowych na wielokulturowym stanowisku 6 w Tominach, pow. opatowski, w latach 2006-2007. Archeologia Polski Środkowowschodniej I0: 9-27.

Szeliga, M. 2009. Znaczenie obsydianu karpackiego w gospodarce surowcowej najstarszych społeczności rolniczych na ziemiach polskich. In J. Garncarski (ed.), Surowce naturalne w Karpatach oraz ich wykorzystanie w pradziejach i wczesnym średniowieczu, 287-324. Krosno.

Szeliga, M. 20I7. The First Chronometric Markings of the Late Stage of the LBK in the Northern Foreland of the Sandomierz Upland. Analecta Archaeologica Ressoviensia I2: 43I-447.

Wąs, M. 2005. Technologia krzemieniarstwa kultury janistawickiej. Łódź.

Wilczyński, J. 20Io. The Techniques of Obsidian Treatment on the Malice Culture Settlement of Targowisko II, Lesser Poland. Przeglad Archeologiczny 58: I-I5.

Wilczyński, J. 20I4. Krzemienny oraz obsydianowy inwentarz kultury ceramiki wstęgowej rytej ze stanowiska Brzezie I7, gm. Kłaj. In A. Czekaj-Zastawny, Brzezie I7. Osada kultury ceramiki wstegowej rytej, 499-546. Kraków. Via Archaeologica. Źródła z badań wykopaliskowych na trasie autostrady A4 w Małopolsce 9.

Williams-Thorpe, O., Warren, S. E. and Nandris, J. G. 1984. The Distribution and Provenance of Archaeological Obsidian in Central and Eastern Europe. Journal of Archaeological Science II: I83-2I2. 
